\title{
SYNERGISTIC USE OF PEAT AND CHARRED MATERIAL IN GROWING MEDIA - AN OPTION TO REDUCE THE PRESSURE ON PEATLANDS?
}

\author{
Jürgen KERN ${ }^{\mathrm{a}}$, Priit TAMMEORG ${ }^{\mathrm{b}}$, Merrit SHANSKIYc, Ruben SAKRABANI ${ }^{\mathrm{d}}$, Heike KNICKER \\ Claudia KAMMANN ${ }^{\mathrm{f}}$, Eeva-Maria TUHKANEN", Geerd SMIDT ${ }^{\mathrm{h}}$, Munoo PRASAD, Kari TIILIKKALAj, \\ Saran SOHI ${ }^{\mathrm{k}}$, Gabriel GASCÓ ${ }^{1}$, Christoph STEINER ${ }^{\mathrm{m}}$, Bruno GLASER $^{\mathrm{n}}$ \\ ${ }^{a}$ Department Bioengineering, Leibniz Institute for Agricultural Engineering and Bioeconomy, \\ Max-Eyth-Allee 100, 14469 Potsdam, Germany \\ ${ }^{b}$ Department of Agricultural Sciences, University of Helsinki, P.O. Box 27 (Latokartanonkaari 5, \\ Plant Production Sciences), FIN-00014, Finland \\ 'Department of Soil Science and Agrochemistry, Estonian University of Life Science, \\ F. R. Kreutzwaldi 5D, 51014, Tartu, Estonia \\ ${ }^{d}$ Cranfield Soil and Agrifood Institute, School of Water, Energy and Environment, Cranfield University, \\ MK43 OAL, United Kingdom \\ ${ }^{e}$ Instituto de Recursos Naturales y Agrobiologia de Sevilla (IRNAS-CSIC), Avenida Reina Mercedes 10, 41012 Sevilla, Spain \\ ${ }^{f}$ Department of Soil Science and Plant Nutrition, WG Climate Change Research for Special Crops, \\ Hochschule Geisenheim University, Von-Lade Str. 1, D-65366 Geisenheim, Germany \\ ${ }^{8}$ Natural Resources Institute Finland (Luke), Toivonlinnantie 518, 21500 Piikkiö, Finland \\ ${ }^{h}$ European Competence Center for Peatland and Climate Wagenfeld, Auf dem Sande 11, D-49419 Wagenfeld, Germany \\ ${ }^{i}$ Compost/AD Research \& Advisory (IE, CY), Naas, Ireland \\ ${ }^{j}$ Natural Resources Institute Finland (Luke), Tietotie 2, 31600 Jokioinen, Finland \\ ${ }^{k} U K$ Biochar Research Centre, University of Edinburgh, EH9 3FF, United Kingdom \\ lDepartamento de Producción Agraria, ETSI Agrónomos, Universidad Politécnica de Madrid, \\ Ciudad Universitaria, 28040 Madrid, Spain \\ ${ }^{m}$ Organic Plant Production and Agroecosystems Research in the Tropics and Subtropics, \\ University of Kassel, Stein str. 19, 37213 Witzenhausen, Germany \\ ${ }^{n}$ Soil Biogeochemistry, Institute of Agronomy and Nutritional Sciences, \\ Martin Luther University Halle-Wittenberg, von-Seckendorff-Platz 3, 06120 Halle, Germany
}

Submitted 12 May 2016; accepted 17 Jan. 2017

\begin{abstract}
Peat is used as a high quality substrate for growing media in horticulture. However, unsustainable peat extraction damages peatland ecosystems, which disappeared to a large extent in Central and South Europe. Furthermore, disturbed peatlands are becoming a source of greenhouse gases due to drainage and excavation. This study is the result of a workshop within the EU COST Action TD1107 (Biochar as option for sustainable resource management), held in Tartu (Estonia) in 2015. The view of stakeholders were consulted on new biochar-based growing media and to what extent peat may be replaced in growing media by new compounds like carbonaceous materials from thermochemical conversion. First positive results from laboratory and greenhouse experiments have been reported with biochar content in growing media ranging up to 50\%. Various companies have already started to use biochar as an additive in their growing media formulations. Biochar might play a more important role in replacing peat in growing media, when biochar is available, meets the quality requirements, and their use is economically feasible.
\end{abstract}

Keywords: biochar, greenhouse gases, growing media, horticulture, organic matter, peatland, peat extraction restoration.

Corresponding author: Jürgen Kern

E-mail: jkern@atb-potsdam.de 


\section{Introduction}

Peatlands are wetlands with a thick $(>30 \mathrm{~cm})$ water-logged organic layer (peat) made up of dead and decaying plant material. They provide environmental services such as biodiversity, carbon (C) storage, regulation of the local water quality and local hydrology conditions including flood protection. They are also considered important C sinks, but as soon as a peatland is drained, aerated, limed and fertilised or when peat is extracted, the organic matter decomposes quickly and turns into a source of greenhouse gases (GHG). Peat has been used as a source of energy since centuries. Today peat is not considered to be a renewable resource anymore due to its very long regeneration time. However, peat extraction continues, due to the high demand in horticulture (Joosten, Clarke 2002; Renou-Wilson, Farrell 2009).

Worldwide about 4 million $\mathrm{km}^{2}$ are covered by peatland, equivalent to $3 \%$ of the land surface (Table 1). The total volume of peat cannot be determined accurately, since for most countries there is no information about the average thickness of the peat layer available. Taking a mean thickness of $1.5 \mathrm{~m}$ as given by Immirzi et al. (1992), a peat volume in situ can be calculated to nearly 800 billion $\mathrm{m}^{3}$ within Europe.

In Central Europe, large areas of peatlands have already been extracted. In the European Union, Germany, the Netherlands, Italy, Spain, and other countries depend on the supply of peat from Northern territories such as the Baltic States, in order to maintain or even expand their horticultural production. The Baltic and Scandinavian countries still have large reservoirs of peatlands as shown by Montanarella et al. (2006).

Total peat extraction can be estimated at $25 \mathrm{Mm}^{3}$ year $^{-1}$ for Finland, 15-20 $\mathrm{Mm}^{3}$ year $^{-1}$ for Estonia, 9-11 $\mathrm{Mm}^{3}$ year $^{-1}$ for Ireland and $7 \mathrm{Mm}^{3}$ year $^{-1}$ for Germany. In Germany, it is expected that the amount of imported peat from Northern and Eastern Europe will increase from $1-2 \mathrm{Mm}^{3}$ up to $7-8 \mathrm{Mm}^{3}$ in the next 20 years, as the German peat resources growth has been exhausted (UBA 2016). Also in Spain, comparable to other Southern European areas, the inland peat extraction cannot satisfy the needs of the local horticultural industry and about 142,000 $\mathrm{t}$ were imported in 2012 (Marchán-Sanz et al. 2014). Thus, the availability of sustainable substrates meeting the quality standards at low cost is of particular interest for European peat-using countries. The current $C$ shift from the Northern to the Central and Southern European countries leads to a loss of $\mathrm{C}$ to the atmosphere as a result of both, peatland degradation and unavoidable mineralisation processes during the use of peat in agriculture and horticulture (Fig. 1).

Since peat is rather cheap and has nearly unbeatable beneficial properties for horticultural purposes, it cannot easily be replaced with alternative materials. Hence, it still remains the predominant constituent of growing media, i.e. materials other than soil in situ, in which plants are grown (CEN Report CR 13456:1999). Other common organic input materials often used to reduce the peat fraction in growing media are compost, treated wood fibres, coir, composted bark, digestates, Sphagnum moss and inorganic materials such as perlite, vermiculite, clay granules, pumice and lava rock. Although growers are interested in new compounds for growing media, the alternative materials do not have the same properties, are expensive or not available compared to peat (Schmilewski 2008). However, the demand of hobby gardeners and consumers for peat free growing media and soil conditioners is increasing rapidly. As potential new group of material, chars (biochar, HTC char) derive from the thermal carbonisation of biomass are presently discussed (Tian et al. 2012; Busch et al. 2013; Steiner, Harttung 2014; Mendez et al. 2015; O'Toole et al. 2016). Since biochar is characterised by a high porosity and a high water holding capacity, it is not only dedicated to replace peat, but may also be usable as a substitute for constituents, which are already established in the growing media market, but which have a limited supply (Mendez et al. 2015). Moreover, a reduction of the peat component in growing media may reduce GHG emissions associated with peat extraction and use, dependencies on peat sources for consumer countries, and the pressure on peatlands.

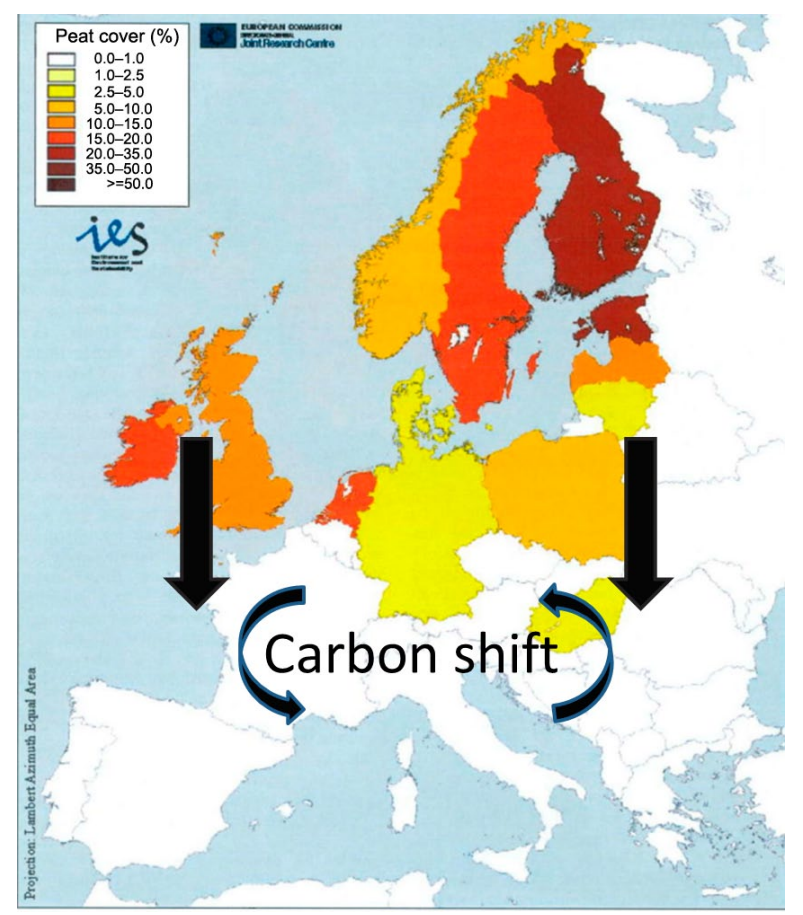

Fig. 1. Relative cover (\%) of peat and peat-topped soils $(0-30 \mathrm{~cm})$ across Europe according to Montanarella et al. (2006). Currently there is a shift of peat from North Europe to Central and South Europe with C loss by mineralisation 
Since peat resources are limited and the supply of new substrates is urgently needed for the production of growing media, a workshop of the EU COST Action TD1107 Biochar as option for sustainable resource management was hosted by the Estonian University of Life Sciences in Tartu (Estonia) in May, $4^{\text {th }}-6^{\text {th }} 2015$. This workshop aimed to stimulate discussions on opportunities for using biochar in synergy with peat as constituents of growing media. The key questions were (i) whether char materials can be combined with other non-peat materials; (ii) whether biochars represent a realistic alternative to substitutes such as compost etc. and (iii) up to which amount biochar may be added to growing media. Finally, the acceptance of new biochar based growing media by stakeholders such as amateur and professional gardeners was elucidated.

The aim of this paper is to compare characteristics of peat and biochar and evaluate options where there can be synergies to replace peat as growing media.

\section{Characteristics of peatlands and its organic matter}

In peatlands plant production exceeds the decay, consequently a $\mathrm{C}$ surplus is accumulated as peat, resulting in a positive $\mathrm{C}$ balance and accumulation of $\mathrm{C}$ stocks. They represent unique biological, environmental and economic resources (Clarke, Rieley 2010). Peatlands occur at all continents, from the tropical to boreal and Arctic zones and from sea level to high alpine conditions. The largest known areas are found in Canada and Alaska, Northern Europe and Western Siberia, Southeast Asia, and parts of the Amazon basin, where more than $10 \%$ of the land area is covered with peatlands. The total area of peatlands on Earth is about 4 Million $\mathrm{km}^{2} .13 \%$ of that area is occurring in Europe (Table 1). In Central Europe, most peat started to be formed after the retreat of the glaciers at the end of the last ice age, around 12,000 years ago (Dudová et al. 2013).

Table 1. Global peatland area by region (World Energy Council 2013)

\begin{tabular}{lcc}
\hline \multicolumn{1}{c}{ Region } & Area $\left(\mathrm{km}^{2}\right)$ & $(\%)$ \\
\hline Central and North America & $1,762,267$ & 44.4 \\
\hline Asia & $1,490,361$ & 37.5 \\
\hline Europe & 525,668 & 13.2 \\
\hline South America & 130,800 & 3.3 \\
\hline Africa & 56,165 & 1.4 \\
\hline Antartica,Oceania & 8.048 & 0.2 \\
\hline Total & $3,973,309$ & 100.00 \\
\hline
\end{tabular}

\subsection{Peat formation}

Peat is a heterogeneous mixture of more or less decomposed plant material, microbial remains and their secondary metabolites that have accumulated in a watersaturated environment due to inhibited decay under acidic and anaerobic conditions. Peat deposits are classified as Histosols according to the World Reference Base of soil resources (IUSS Working Group WRB 2007). Usually peat accumulates slowly at a rate of approximately one $\mathrm{mm}$ per year (Keddy 2010), which requires biomass production at a greater rate than its chemical breakdown. Most of the biomass derives from the wetland vegetation such as Sphagnum and other mosses, sedges, and shrubs. The overriding physical conditions controlling peat formation is a high water table. Since oxygen moves very slowly in stagnant water, it is used up rapidly by microorganisms (Rydin, Jeglum 2006). In regard of this, peat deposits consist of two layers: an aerobic upper layer, the acrotelm and the lower, waterlogged, constantly anoxic and usually more humified layer, the catotelm (Moore 1989). In the top $20 \mathrm{~cm}$ of the surface, microbial activity is commonly relatively high (Casagrande et al. 1985) but with increasing depth it decreases and anaerobic bacterial activity dominates over fungal and aerobic bacterial degradation. Below the level of anaerobic activity, virtually all biological activities cease. The process of disintegration stops before it has been completed and the partially decomposed remains of the peat-forming plants slumber through millennia (Fuchsman 1980). The accumulation of peat usually causes increasingly more acidic and nutrient-poor conditions, both reducing microbial activity and organic matter degradation (Mitsch, Gosselink 2000).

\subsection{Role of peat in the ecosystem}

Peatlands belong to the most important terrestrial C reservoirs on Earth (Dunn, Freeman 2011). Although they cover only $3 \%$ of terrestrial ecosystems, they contain about $550,000 \mathrm{Mt} C$ (Parish et al. 2008) accounting for $27 \%$ of the global soil C stock (Janzen 2004). Peat deposits are characterised by a high C content of about $50 \%$ of the dry organic matter. The accumulation of peat depends on the balance between plant productivity and $\mathrm{C}$ losses through the process of decay, leaching and fires. About $5-10 \%$ of the biomass produced in peatlands annually ends up as peat (Joosten, Clarke 2002), providing the major global store of terrestrial C besides (non-peat) soil organic C (Bonn et al. 2014).

The question arises if the existing peatlands are still net $C$ sinks or sources. Intact peatlands in Europe seem to be in a neutral, alternating state with regard to their $\mathrm{C}$ balance. Koehler et al. (2011) for example found in a six years $\mathrm{C}$ balance study $\left(\mathrm{CO}_{2}-\mathrm{C}, \mathrm{CH}_{4}-\mathrm{C}\right.$ and dissolved organic $\mathrm{C}$ (DOC)) that the Irish peatland was a net $\mathrm{C}$ sink in four of the years However, anthropogenic impact on peatlands can severely affect the overall balance of $\mathrm{CO}_{2}$ equivalents via the formation or consumption of the greenhouse gases $\mathrm{CO}_{2}, \mathrm{~N}_{2} \mathrm{O}$ and $\mathrm{CH}_{4}$. Peatlands become a significant source 
of $\mathrm{CH}_{4}$ and $\mathrm{DOC}$ when the water table drops. Increased emissions of $\mathrm{CO}_{2}$ and $\mathrm{CH}_{4}$ can explain the switchover of the peatland from a sink to a source of carbon. The huge $\mathrm{C}$ stocks, which built up during the last millennia are being considerably affected by humans today. Drainage and excavation of peatlands augmented by more than $20 \%$ from 1,058 Mt in 1990 to 1,298 Mt in 2008 (Joosten 2009). The increase was primarily caused by the demand of new farmland in developing countries and does not include the loss of peat by fires. The $\mathrm{EU}$ (27) was with $174 \mathrm{Mt} \mathrm{CO}_{2} \mathrm{yr}^{-1}$ the second largest emitter of drainage-related peatland$\mathrm{CO}_{2}$ emission after Indonesia with $500 \mathrm{Mt} \mathrm{CO}_{2} \mathrm{yr}^{-1}$ (Butler 2009). Only $1 \%$ of European peatlands can be considered to be intact and still peat-accumulating (Koster, Favier 2005). That means that peatland areas in Western Europe have mostly lost their function as $\mathrm{C}$ sinks.

Peatlands contain about $10 \%$ of available freshwater resources and many of them are directly connected to rivers, thereby having a significant effect on the water cycles in the catchment (Bullock, Acreman 2003; Holden $2005)$. Peat can retain large amounts of water $(90-95 \%$ of its mass), and therefore it has commonly been stated that peatlands reduce floods by "acting as a sponge" (Bullock, Acreman 2003; Holden 2005). This is usually the case, but water saturated headwater peatlands may quickly carry rainfall downstream and thus also increase the flood peaks or volumes (Bullock, Acreman 2003). Peatlands are adapted to the extreme conditions of high water and low oxygen content, and low availability of plant nutrients. As reported by Holden (2005), their water chemistry varies from alkaline (fens or peatlands depending on groundwater) to acidic (bogs or peatlands depending on precipitation). Bogs can retain the majority of the nutrients (i.e. P, $\mathrm{Ca}, \mathrm{K}, \mathrm{Na}$ and $\mathrm{Mg}$ ) that enter the system by rain, acting thus as nutrient traps (Verry, Timmons 1982). In general, peatlands are rather scarce in plant-available nutrients as the bogs receive limited supply of nutrients and the accumulation of peat further immobilises the nutrients. This caused peatland plants to adapt to nutrient shortage (Joosten, Clarke 2002).

Peatlands are unique ecosystems forming distinct units of local, regional, national and global importance for biodiversity maintenance at genetic, species and habitat levels. They contain species that are found only or mainly in peatlands and are home to some of the rarest species of plants and animals. Mires and peatlands are generally characterised by extreme conditions, which call for special adaptations of the species that live there. For instance, leaves of higher plants are sclerophyllic and thicker in response to nutrient limitations, moss genera such as Sphagnum can accumulate nutrients by cation exchange mechanisms (Clymo, Hayward 1982) and some specialised plant species feed on parasitism (e.g. Scrophulariaceae; Joosten, Clarke 2002) or carnivory (e.g. Droseraceae;
Brewer et al. 2011). The high water level and the consequent scarcity of oxygen in the root layer requires adaptations in physiology, anatomy and growth form in order to provide the root system with oxygen and thereby to enable a detoxification of substances, which are produced under anaerobic conditions. Abiotic variables such as $\mathrm{pH}$, aeration and temperature had been reported to be the main factors controlling the microbial activity and community composition in peatlands (Preston, Basiliko 2016). The importance of habitat and biodiversity management and the protection of biological services and ecosystem processes have been recognized internationally more than 20 years ago (CBD 1992). The globally observed loss of biodiversity requires efficient actions such as the restoration of degraded peatlands (Tanneberger, Wichtmann 2011; Ramchunder et al. 2012).

\section{Peatland management}

Peatlands are used and managed for many different purposes. Since 1800, the global peatland area has been reduced by $10-20 \%$ through climate change and human activities, particularly by drainage for agriculture and forestry (Clarke, Rieley 2010; Table 2). Undrained peatlands are valuable habitats for a wide range of biodiversity and ecosystem services and many are managed as natural reserves. Besides agriculture and forestry, peatlands are used for instance also for peat extraction to provide energy and for growing media.

Table 2. Global area and proportions of peat(land) use according to Clarke and Rieley (2010)

\begin{tabular}{lcc}
\hline \multicolumn{1}{c}{ Use } & Area $\left(\mathrm{km}^{2}\right)$ & $(\%)$ \\
\hline Undisturbed peatlands & $3,500,000$ & 85.91 \\
\hline Temperate agriculture & 300,000 & 7.36 \\
\hline Tropical agriculture & 120,000 & 2.95 \\
\hline Forestry & 150,000 & 3.68 \\
\hline Growing media & 2,000 & 0.05 \\
\hline Energy & 2,000 & 0.05 \\
\hline Total & $4,074,000$ & 100.00 \\
\hline
\end{tabular}

In general, peat is considered a non-renewable resource, yet in some regions of northern Europe, the remarkable growth of new peatlands facilitates the use of it as a renewable resource. For instance, in Estonia, the annual peat generation in mires is estimated to equal to $2,600,000$ tons, this estimate is the basis for allowing the annual production up to this amount. The fulfilment of the quota is monitored with environmental permits with a new permit being granted if some unused quota is still available. The peat extraction controlled in such a way may be justified today, when the requirements for conservation 
of the vast majority of pristine or semi-natural peatlands are fulfilled. The Foundation Responsible Produced Peat (2014) is certifying peat extraction only from formerly degraded peatland including a restoration after-use.

\subsection{Exploitation}

While the majority of arctic and subarctic peatlands have been little utilised for agricultural purpose, in other parts of the world, peatlands are intensively used, as for example in Indonesia, where huge areas of peat swamp forests have been deforested and drained for the establishment of palm oil plantations. Up to $20 \%$ of peatlands on Earth are used today or considered for agriculture mostly in form of meadows and pastures (Strack 2008). To meet the full requirements of cultivated pasture plants, peatlands have to be drained. One advantage for agricultural use of drained peatland is the initial release of nitrogen by enhanced mineralisation. Ploughing and the physical and chemical alteration of soil properties however, cause a strong increase in $\mathrm{CO}_{2}$ emissions (Oleszczuk et al. 2008). One example is the northern part of Germany, where $75 \%$ of former peatlands are being used as intense agricultural grassland or cropland. The drainage of the peat body is causing subsidence of one to two $\mathrm{cm}$ per year due to shrinking, sagging and mineralisation. By a change of soil management and groundwater control, nowadays farmers and water authorities strive towards to develop new strategies to mitigate the emission of GHG (Wichtmann, Schäfer 2007).

\subsection{Restoration}

Restoration is directed to the recovery of degraded peatlands and depends on the definition of a better state and how this is realised (Schumann, Joosten 2008). Restoration of peatland aims to preserve and improve function of the disturbed ecosystem. The development of biodiversity and species protection is traditionally in focus of the measures. Also C storage preservation and development of a C sink is an important goal of recent restoration plans. Various international climate change conventions promote peatland restoration as a key contribution towards reaching both, biodiversity and climate targets (IPCC 2014). Regional C markets have been suggested to fund peatland restoration (Bonn et al. 2014).

A recovery of functional peatland ecosystems is strongly dependent on steady water table characteristics even in summer (Menberu et al. 2016). In restoration, the first step is to raise the water table of the peatland (fen or bog) by e.g. closing ditches, building damns and removing trees. Once the peat layers get wet, the vegetation will gradually change from forest to bog vegetation. The formation of peat will recommence if hammock Sphagnum mosses are present in a peat bog. In fens the existence of reed, sedges or e.g. alder is necessary for the peat formation.
Instead of peat mining, only the upper living parts of Sphagnum moss can be harvested and used as growing media with properties very close to that of peat (Silvan et al. 2012). Sphagnum farming can serve as a restoration method of disturbed peatlands, and at the same time it supplies a renewable growing media with smaller environmental impact than peat mining. By this approach Sphagnum regeneration starts from the remaining fragments with a growth of about $1 \mathrm{~cm}$ per year. Thus, after 25 years, about 2-5 Mg dry mass ha ${ }^{-1}$ can be harvested (Silvan et al. 2012; Reinikainen et al. 2012; Tahvonen et al. 2015).

\section{Use of peat}

The total use of peat in the EU in 2005 was $68 \mathrm{Mm}^{3}$ as reported by main producer and consumer countries. $50 \%$ was used for energy generation, $42 \%$ for growing media production, $5 \%$ as soil amendment material and $3 \%$ for other uses (CoConcept 2008). This may be construction and insolation materials, animal stable litter, alcoholic drinks, water purification systems, balneology, therapy, medicine and textiles (Joosten, Clarke 2002).

\subsection{Energetic use of peat}

For a long time, peat has been excavated and used for its energy value, providing an important regional and national source of heat and power. This kind of use is still ongoing with a worldwide consumption of $17.3 \mathrm{Mt}$ per year (World Energy Council 2013). More than 99\% of this peat is extracted and burned in Europe. Although the share of peat is only $0.2 \%$ of the primary energy consumption in the $27 \mathrm{EU}$ countries, this part is being considered as one source to meet the EU's energy security policy. The most important peat extractors and consumers for energy generation are Finland, Ireland, Belarus and Russia (Fig. 2). The highest annual peat extraction within Europe occurs in Finland with about $25 \mathrm{Mm}^{3}$, of which $90 \%$ is

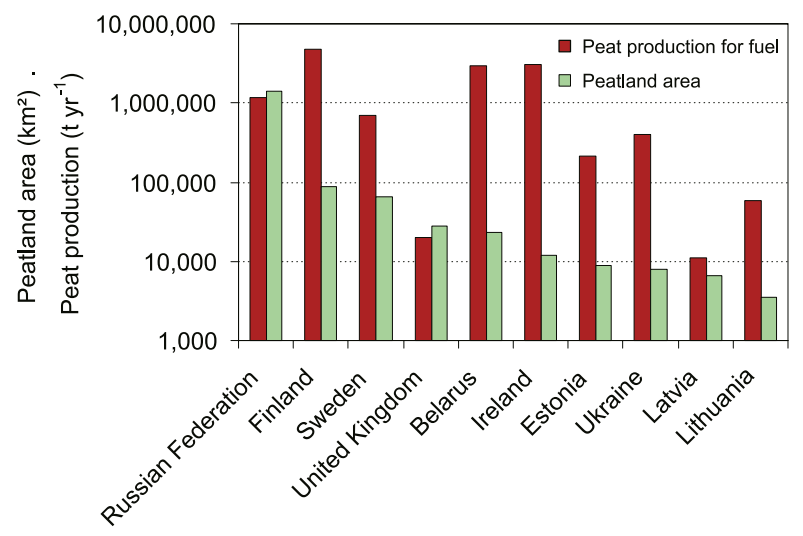

Fig. 2. Country-related pre-disturbance peatland areas compared to their annual peat extraction for energy purpose in Europe and the Russian Federation in 2008 (Data from World Energy Council 2013) 
energetically used and less than 5\% is used in growing media. In energy policy, peat is regarded as non-renewable material and treated as fossil fuel. In the national policy, importance of the use of domestic fuels is increasing and peat will thus remain to be an important energy source in Finland (Karhunen et al. 2015). Only Latvia, Liechtenstein, Norway, the Russian Federation, Sweden, and Ukraine still have more than half of their original mire area left, whereas in some Central and Southern European countries, the formerly dominant landscape type has been almost completely destroyed (Joosten, Clarke 2002).

\subsection{Use of peat in horticulture}

Peat was the organic component of the first standardised growing media for plants in containers (Lawrence, Newell 1939). Their mixtures consisted of loam, peat and sand at a ratio of 7:3:2. Further works in Germany, Finland and Ireland showed that peat could be used as a growing medium in its own right both for container plants and for vegetable and cut flower production (Maher et al. 2008).

The peat fraction is used to increase the air space of growing media especially for crops that require high aeration and for long-term crops grown in large containers. Peat offers an ideal substrate for horticultural plant production. It forms the basis of growing media that is readily available, easily processed, uniform, high performance and cost-effective. In 1999, nearly $40 \mathrm{Mm}^{3}$ of peat were used across the world in horticulture (Joosten, Clarke 2002). In Europe, approximately $90 \%$ of all growing media for the professional and private markets are peat-based. The major advantages of Sphagnum peat as constituent of growing media include (i) very low salinity, (ii) cellular structure, ensuring a good water holding capacity and air volume, (iii) low $\mathrm{pH}$ and nutrient status, allowing easy adjustment by the addition of crop-specific fertilisation and liming, (iv) low number of pathogens, pests and weeds, (v) easy handling, processing, grading and blending, (vi) availability of peat products on a world-wide basis (see Bigelow et al. 2004; Desbiens et al. 2008).

More than $37 \mathrm{Mm}^{3}$ of growing media are produced in the EU every year - by a few large companies (Klasmann-Deilmann and Bord $\mathrm{Na}$ Mona with $3.5 \mathrm{Mm}^{3}$ and $2.0 \mathrm{Mm}^{3}$ per year, respectively) and several hundreds of small businesses - on which a large part of European horticulture industry depends.

Growing media must ensure basic physical and chemical properties. In today's sophisticated nurseries, tailor-made fertilisers and crop-specific growing media are essential. Sorting harvested peat into various size fractions by sieving provides peat fractions with a wide range of physical properties on a predictable basis. Table 3 shows the relationship between particle size and the most important physical properties of fractionated peat (Maher,
Table 3. Physical properties of fractionated peat according to Maher and Prasad (1993)

\begin{tabular}{cccc}
\hline $\begin{array}{c}\text { Size } \\
(\mathrm{mm})\end{array}$ & $\begin{array}{c}\text { Pore space } \\
(\%)\end{array}$ & $\begin{array}{c}\text { Air space } \\
(\%)\end{array}$ & $\begin{array}{c}\text { Easily available } \\
\text { water }(\%)\end{array}$ \\
\hline $0-3$ & 94.4 & 13.7 & 37.3 \\
\hline $6-12$ & 92.0 & 36.3 & 17.8 \\
\hline $10-25$ & 91.5 & 40.9 & 14.5 \\
\hline
\end{tabular}

Prasad 1993). High air space volume in the 6-12 $\mathrm{mm}$ and the $10-25 \mathrm{~mm}$ fractions were well above those recommended for pot plants grown in flood benches and for nursery stock crops (Kipp et al. 2000).

As peat has a low $\mathrm{pH}$ and a very low level of fertility, it needs the addition of lime and nutrients in order to support good plant growth. The amount of nutrients needed, depends on the species being grown and the stage of development. Seeding and propagation require only a low level of nutrients in contrast to the growth of more mature plants (Maher et al. 2008).

\subsection{Components used as additive or for peat replacement}

The scrutiny of peat use has led to consideration of various alternatives, some of which have been assessed as 1:1 replacements. When considering new ingredients of growing media whether mixed with peat, or on its own at a technical level there are important physical, chemical and biological factors to be considered. From a physical point of view, bulk density of components of growing media should be low but mechanical stability and total pore space should be high. The particle size distribution affects aeration and water-holding capacity. Especially the fraction $<1 \mathrm{~mm}$ plays a key role for air capacity and water availability. Standardised tests have been developed for growing media and soil improvers under the auspices of the European Committee for Standardisation during the last two decades (Baumgarten 2013). Among the organic components suitable and already established in growing

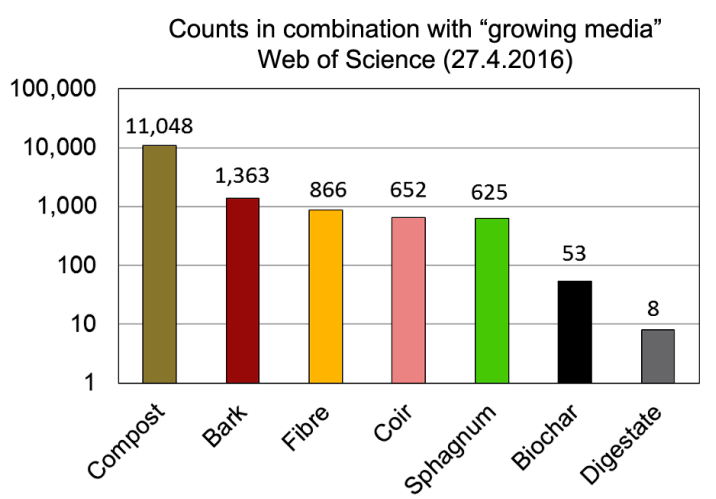

Fig. 3. Overview about the main components in growing media and their corresponding number of related publications listed in the Web of Science in April 2016 
media are composts, bark, wood fibre products and coir (Schmilewski 2008). Sphagnum moss, which is the most common constituent of peat itself is also gaining importance. The number of scientific papers about different candidate materials reflects the relevance of each new component in horticulture (Fig. 3).

Today, compost plays the major role as a peat substitute (Prasad et al. 2008). Compost made from green waste has a relative high salt content and cannot be considered as an appropriate substrate by itself but can be used as a component for potting mixtures in many peat-based cultivations. Particularly the disease suppressive properties of composts can play an important role in plant cultivation (Van der Gaag et al. 2007).

Veeken et al. (2005) reported that up to $60 \mathrm{vol} \%$ peat replacement by wet-sieved biowaste compost did not affect cucumber growth. However, disease suppressiveness against the plant pathogen Pythium ultimum of the potting mixes linearly increased from 31 to $94 \%$ when the compost amendment rate was increased from 20 to $60 \%$. Disease suppressiveness significantly correlated with basal respiration and can be explained by the fact that plant pathogens are reduced by soil microorganisms. However, plant yield was significantly lower with compost due to inadequate nutrient supply. The authors concluded that compost from wet-sieved biowaste has high potential to replace peat in growing media for the professional market. Sphagnum moss is an excellent growth medium because its chemical and physical properties are quite similar to peat, with the exception of lower content of lignin $(<10 \%)$ than in peat $(20-50 \%)$ as reported by Prasad and Maher (2013). The amount of easily available water is similar in peat and Sphagnum media (Tahvonen et al. 2015).

Other promising options, biochars, are being discussed as additives or substitutes for peat in growing media. Biochars are produced from biomass by heating it in oxygen-depleted environment and are targeted to be used in any way that does not include the quick return of its carbon to the atmosphere. In recent years biochars have been found to be effective tools for waste management, soil remediation, control of GHG emissions and improvers of agricultural soils and soil-less media in horticulture (Lehmann, Joseph 2015; Shackley et al. 2016). The typically high porosity and surface area of biochars promote the retention of water and the sorption of nutrients. Further properties of biochars, which may be also a benefit for growing media are their low nutrient content (Gaskin et al. 2008), particularly when produced from nutrientpoor feedstock such as wood, their exceptional structural stability (Tian et al. 2012) and its extremely recalcitrance against microbial decay (Kuzyakov et al. 2014). Compared to peat, a slowed down mineralisation of biochar opens a new way of carbon storage and thus a potential for $\mathrm{CO}_{2}$ mitigation (see Kammann et al., this issue). Biochars can also be combined with compost and used as a soil amendment with synergetic effects unfolding benefits for water infiltration and retention (Liu et al. 2012) as well as for nutrient cycling (Steiner et al. 2015; Glaser et al. 2015).

Even nutrient-rich feedstocks of biochar such as sewage sludge are being discussed to become in a carbonised form one component in growing media. Recent studies found, that biochars of sewage sludge amendments increased the bioaccumulation of phosphorus in rice plants and also their shoot biomass by up to $92 \%$. However, also the bioaccumulation of $\mathrm{Cd}$ and $\mathrm{Zn}$ increased (Khan et al. 2013). These results are corresponding with the increased availability of $\mathrm{Zn}$, As and $\mathrm{Cd}$ for all 19 biochars produced at a process temperature of $750{ }^{\circ} \mathrm{C}$ (Buss et al. 2016). Although some progress has been made in the development of new growing media, the search for substitutes of peat remains as long as there is no clean and affordable material suitable to substitute peat entirely (Michel 2010).

\section{Charred materials as new constituents of growing media}

Little is currently known on the properties of individual ingredients and their compatibility and combinability. So, it is not yet possible to define a mix that would be certain to provide the best properties, without extensive case by case testing. Drawing on a range of ingredients also introduces risk in terms of each ingredient's quality as well as its future absolute and economic availability. In the case of biochar, the prospect for a close involvement in the development of pyrolysis facilities recedes if it only provides an "additive" or one of a number of minor constituents. Irrespective of purchase prices, the logistics associated with creating a mix also involves additional cost in terms of labour, equipment and procurement. In terms of reducing peat use, a single ingredient in a mix may not displace enough peat to warrant an intensive investigation of itself, at least not by a single company, organisation or country. It seems that this has presented a significant barrier to biochar adoption in horticulture so far. A further question concerns the parameters for mix optimisation, whether there should be maximum contents, whether peat should be included at all (Sohi et al. 2013).

\subsection{Functional feasibility}

The proportion of char in a growing media will depend on costs and benefits. These benefits may include: i) biological e.g. pathogen interaction (Hammer et al. 2015; De Tender et al. 2016), ii) physical relating to handling and appeal, e.g. particle size, integrity, internal porosity and activity of internal surfaces and iii) chemical properties like plant nutrient supply or interactions with agro-chemicals and fertiliser nutrients such as nitrogen, phosphorus and potassium (Prendergast-Miller et al. 2014). 
One crucial factor that determines the suitability of a char as component in growing media is the process of biomass carbonisation. Pyrolysis of dry biomass at temperatures around $400-600{ }^{\circ} \mathrm{C}$ creates biochars under oxygen-limiting conditions. Hydrothermal carbonisation (HTC) of wet biomass at temperatures between 180 and $250{ }^{\circ} \mathrm{C}$ creates a char that is brown in colour and less stable than pyrolysis biochar (Libra et al. 2011; Lanza et al. 2015). Biochar and HTC char have markedly different physico-chemical properties (Schimmelpfennig, Glaser 2012). The chemical properties playing a key role in the quality of growing media are electrical conductivity (EC) and $\mathrm{pH}$ value. They are similarly low in peat and HTC char (Table 4). In terms of toxicity, attention has to be paid to fresh HTC chars, which often contain compounds such as organic acids and phenols, which may affect the seed germination and the growth of seedlings (Bargmann et al. 2013; Busch et al. 2013). In case of biochars deriving from pyrolysis, polycyclic aromatic hydrocarbons (PAH) and dioxins can be formed due to the kind of biomass source, process temperature and time (Schimmelpfennig, Glaser 2012). Hale et al. (2012) reported that PAH disappeared from the biochar with increasing temperature and time of pyrolysis. However, as shown in section 4.3, compounds, which are phytotoxic at high concentrations may also stimulate plant growth at low concentrations (see Frenkel et al., this issue). Besides the chemical properties, which are strongly influenced by feedstock and carbonisation technology, particle size is considered as important for the suitability of the char as a peat substitute or additive (Steiner et al. 2015). Functional improvement of peat substitutes could also be achieved by a post-treatment such as washing, composting and activating for particular chemical and biological effects (Schulze et al. 2016; Agegnehu et al. 2016; Mukherjee, Halder 2016). Modified chars may become a base for a compound ingredient or additive. Slow release of mineral nutrients, provision of active surfaces, volatile disease-suppressant compounds and sites for microbial activity can be provided as reported by Sohi et al. (2013). Defining char functional properties linked to feedstock and process conditions can enable a classification of chars to receive standards for chars used in growing media. This could help to introduce this group of compounds into the growing media market.

\subsection{Technological and economic feasibility}

For any manufacturer of growing media, the certainty of future supply is pre-requisite in taking peat replacement into consideration. For this purpose, currently two options exist: (i) to purchase charcoal at the world market, or (ii) to produce char materials. The first option is most probable: although the consistency and basic properties of charcoal may be uncertain or sub-optimal, the
Table 4. Exemplary comparison of ranges of $\mathrm{pH}, \mathrm{EC}$ and $\mathrm{N}$ content of commercial and experimental biochars and HTC chars with peat substrates (Prasad, unpublished), EC - electrical conductivity, N - nitrogen, HTC - hydrothermal carbonisation

\begin{tabular}{llccc}
\hline Material & \multicolumn{1}{c}{$\begin{array}{c}\text { Feedstock } \\
\text { Peat origin }\end{array}$} & $\mathrm{pH}$ & $\begin{array}{c}\mathrm{EC} \\
\left(\mu \mathrm{Cm}^{-1}\right)\end{array}$ & $\begin{array}{c}\mathrm{N} \\
(\% \mathrm{DM})\end{array}$ \\
\hline $\begin{array}{l}\text { HTC } \\
\text { char } \\
(\mathrm{n}=5)\end{array}$ & $\begin{array}{l}\text { Wheat straw, beer } \\
\text { grain, digestate, } \\
\text { sewage sludge }\end{array}$ & $5.1-7.5$ & $108-260$ & $1.2-4.9$ \\
\hline $\begin{array}{l}\text { Biochar } \\
(\mathrm{n}=6)\end{array}$ & $\begin{array}{l}\text { Waste of Wood, oat } \\
\text { and food, maize } \\
\text { silage, paper fibre }\end{array}$ & $8.0-9.9$ & $\begin{array}{l}300- \\
1,400\end{array}$ & $0.5-1.6$ \\
\hline $\begin{array}{l}\text { Peat } \\
(\mathrm{n}=3)\end{array}$ & $\begin{array}{l}\text { non-fertilised Peat } \\
\text { substrate from } \\
\text { Ireland, }\end{array}$ & $4.0-5.7$ & $50-100$ & $0.6-1.5$ \\
\hline
\end{tabular}

investment risk is low. However, compared to the price of peat (around $30 € \mathrm{Mg}^{-1}$ ), charcoal still remains expensive (ca. $300 € \mathrm{Mg}^{-1}$ ), due to the labour intensive nature of the process technology. Charcoal could therefore only function as an additive i.e. minor ingredient today - and therefore would need to have significant benefits. Issues of sustainability associated with much of the charcoal imported into Europe, presents a major reservation. Although small suppliers of locally produced charcoal and biochar exist within Europe, they may not compete economically, selling at a premium price of approx. 500-1,000 $€ \mathrm{Mg}^{1}$ (Shackley et al. 2015). Recently, one example of HTC char has been reported, which may become interesting for horticulturists. Fornes et al. (2015) analysed the production of forest waste hydrochar at industrial plant scale in Spain (800 $t$ of raw material per year) and estimated a price of $140 € \mathrm{Mg}^{-1}\left(47 € \mathrm{~m}^{-3}\right)$. This price, however, is still higher than peat prices, which range from 39 (Sphagnum peat) to $20 € \mathrm{Mg}^{-1}$ (Phragmites peat) on the Spanish market. Furthermore, the price of charcoal effectively sets a lucrative floor price that would limit the economic benefit seen by buyers.

The second option then is appealing - it would create the capacity to produce chars from waste streams that are secure and abundant locally, or arising within the growing media operations. If biochar or HTC char could be produced in such situation at a much lower cost than the market price, it could be profitably integrated into a growing medium. A report from the UK compared the costs for biochar in growing media under different production scenarios and found the lowest net costs (around $44 € \mathrm{Mg}^{-1}$ in 2013) for pyrolysis of pre-digested sewage sludge, when sludge treatment was linked to continuous pyrolysis with energy recovery and power generation (Sohi et al. 2013). In this case, the stabilisation of toxic metals and the absence of contaminants from pre-cursors in feedstock must be ensured. Additional cost reduction can be expected by 
the pyrolytic recycling of growing media into biochar as a sterile ingredient for a new mix in combination with energy generation.

The main barriers are the traditionally low-capital nature of the growing media industry, and the contrasting nature of the expertise required for establishing and operation a carbonisation plant. For this reason, we might envisage a partnership arrangement where it suits waste producers also, to secure a certain disposal route and price. The scale of production could potentially fall below the thresholds required for compliance with Waste Incineration Directive (2000/76/EC). Further, the quality standards of the non-peat constituents need to be clearly defined, and for biochars, the volunteer European Biochar Certificate (European Biochar Foundation 2012) is an important stepping stone on the path for EU-level joint legislation that is currently being developed.

\subsection{Experience with char materials in horticultural practice}

Among the different components suitable for growing media (Section 3.3), char materials belong to a group, which is relatively new and has not been established in the growing media market yet. The main focus of the growing media industry is on growth-supporting properties such as slightly acid $\mathrm{pH}$, high cation exchange capacity, good aeration and a high water-holding capacity in order to guarantee germination and a good plant growth in the juvenile phase.

In areas where peat is not available, char materials are frequently used with success. For instance Steiner et al. (2009) observed the use of rotten tree trunks and biochar in the Brazilian Amazon. This is widespread practice and herbs which are sold in pots are frequently planted in carbonised rice husk as substrate.

To identify the best combination of peat, inorganic compounds such as vermiculite and different doses of chars ranging from 5 to $100 \%$ have already been tested (Table 5). Dumroese et al. (2011) produced pellets from biochar and saw dust (43\% each) with starch and poly-acetic acids as binding agents (7\% each). They reported that mixtures of $75 \%$ peat substrate and $25 \%(\mathrm{v} / \mathrm{v})$ biochar pellets gave ideal physico-chemical properties desired in soilless growing media, i.e. biochar pellets improved the hydraulic conductivity and water availability at lower matric potentials while reducing shrinkage. A similar approach was taken by Vaughn et al. (2013). In this study, different doses of pelletised biochars from wood and wheat straw ranging between 5 and 15\% (v/v) were compared for their effects when replacing peat in growing media. There was an undesirable increase in bulk density, $\mathrm{pH}$ and $\mathrm{EC}$, while having variable effects on porosity (Table 5).

Table 5. Physico-chemical properties of soil-less plant growing media with variable peat and biochar amounts. Means within a column followed by different letter(s) are significantly different $(\mathrm{p}<0.05)$, EC - electrical conductivity

\begin{tabular}{|c|c|c|c|c|c|c|c|c|}
\hline $\begin{array}{c}\text { Biochar } \\
(\%)\end{array}$ & $\begin{array}{c}\text { Substrate and } \\
\text { Feedstock of biochar }\end{array}$ & $\begin{array}{c}\text { Process } \\
\text { conditions }\end{array}$ & $\begin{array}{l}\text { Bulk density } \\
\qquad\left(\mathrm{g} \mathrm{cm}^{-3}\right)\end{array}$ & $\mathrm{pH}$ & $\begin{array}{c}\mathrm{EC} \\
\left(\mathrm{mS} \mathrm{cm}^{-1}\right)\end{array}$ & $\begin{array}{c}\text { Total porosity } \\
(\%)\end{array}$ & $\begin{array}{c}\text { Biomass yield } \\
\text { (\% of peat control) }\end{array}$ & Ref. \\
\hline 0 & $\begin{array}{l}100 \% \text { Peat } \\
\text { Biochar greenwaste }\end{array}$ & & $0.30 \quad \mathrm{~b}$ & $6.22 c$ & $0.67 \mathrm{c}$ & 67.4 a & $\begin{array}{c}\text { Calathea } \\
\text { rodundifolia } \\
100 \mathrm{~b}\end{array}$ & \multirow{3}{*}{$\begin{array}{c}\text { Tian et al. } \\
\text { (2012) }\end{array}$} \\
\hline 50 & \multirow{2}{*}{ Biochar Greenwaste } & \multirow{2}{*}{$\begin{array}{l}160-220^{\circ} \mathrm{C} \\
20 \mathrm{~min}\end{array}$} & $0.37 \mathrm{ab}$ & $7.11 \mathrm{~b}$ & $0.73 \mathrm{~b}$ & $57.2 \mathrm{ab}$ & $122 \mathrm{a}$ & \\
\hline 100 & & & $0.44 \quad \mathrm{a}$ & $7.95 \mathrm{a}$ & $0.92 \mathrm{a}$ & $48.9 \mathrm{~b}$ & $75 \mathrm{c}$ & \\
\hline 0 & $\begin{array}{l}50 \% \text { Vermiculite } \\
50 \% \text { Peat }\end{array}$ & & 0.13 & 5.1 & 1.63 & 91.2 & $\begin{array}{c}\text { Tagetes erecta } \\
100 \mathrm{ab}\end{array}$ & \multirow{7}{*}{$\begin{array}{l}\text { Vaughn } \\
\text { et al. } \\
(2013)\end{array}$} \\
\hline 5 & $50 \%$ Vermiculite & \multirow{3}{*}{$80 \mathrm{~min}$} & 0.15 & 5.4 & 1.69 & 89.4 & $88 \mathrm{~b}$ & \\
\hline 10 & $35-45 \%$ Peat & & 0.16 & 5.5 & 1.71 & 87.7 & $96 \mathrm{ab}$ & \\
\hline 15 & $\begin{array}{l}\text { 5-15\% Biochar from } \\
\text { Hard wood pellets }\end{array}$ & & 0.17 & 5.6 & 1.75 & 87.6 & $98 \mathrm{ab}$ & \\
\hline 5 & $50 \%$ Vermiculite & \multirow{3}{*}{$180 \mathrm{~min}$} & 0.14 & 5.4 & 1.72 & 90.4 & $107 \mathrm{ab}$ & \\
\hline 10 & $35-45 \%$ Peat & & 0.15 & 5.6 & 1.81 & 92.5 & $115 \mathrm{a}$ & \\
\hline 15 & $\begin{array}{l}5-15 \% \text { Biochar from } \\
\text { Wheat straw }\end{array}$ & & 0.15 & 5.8 & 1.90 & 89.8 & $109 \mathrm{ab}$ & \\
\hline 0 & $100 \%$ Peat & & & 4.5 & 0.63 & & $\begin{array}{c}\text { Helianthus annuus } \\
100 \\
\end{array}$ & \multirow{5}{*}{$\begin{array}{c}\text { Steiner, } \\
\text { Harttung } \\
(2014)\end{array}$} \\
\hline 25 & \multirow{4}{*}{$\begin{array}{l}\text { Biochar from wood } \\
\text { without bark }\end{array}$} & \multirow{4}{*}{$\begin{array}{l}600{ }^{\circ} \mathrm{C} \\
60 \mathrm{~min}\end{array}$} & & 4.8 & 0.47 & & 6 & \\
\hline 50 & & & & 5.0 & 0.45 & & 81 & \\
\hline 75 & & & & 6.3 & 0.35 & & 90 & \\
\hline 100 & & & & 9.0 & 0.61 & & 72 & \\
\hline
\end{tabular}


The greenhouse experiments with tomato (Solanum lycopersicum L.) and marigold (Tagetes erecta L.) showed that biochar had no negative effect on yields, but significantly increased plant heights in all treatments. Altland and Locke (2012) focused on the nutrient retention and leaching from a soil-less substrate applied at rates of 1,5 and $10 \%(\mathrm{v} / \mathrm{v})$ biochar to a peat-based substrate. They found that biochar might be effective in moderating extreme fluctuations of nitrate levels in container substrates over time. The upper limit of biochar doses in growing media was tested by Tian et al. (2012), who used pure peat substrate, pure biochar and a 1:1 mixture of peat/biochar. The highest biomass yield of the ornamental plant Calathea was found with the peat/biochar mixture, which was $22 \%$ higher compared to peat alone. In another study, large doses of $0 \%, 25,50,75$, and $100 \%(\mathrm{v} / \mathrm{v})$ biochar mixed with peat were tested in trials besides other growing media such as perlite, clay granules, and pure peat regarding the growth of Helianthus annuus (Steiner, Harttung 2014). The miniature sunflower was growing well in all substrates and mixtures under study. It was emphasised that acidic peat-based growing media, which are usually limed to adjust the $\mathrm{pH}$ for different demands of crops, can work without lime when biochar is used as an additive.

Besides the dose of char in a growing medium, the raw material and the carbonisation technique play key roles in the physico-chemical properties of chars. Comparing biochars and HTC chars from forest waste, for example, resulted in a higher germination index for HTC char for both lettuce and cress (Fornes et al. 2015). In biotoxicity testing, Busch et al. (2012) used biochar or HTC char in peat at mixture rates of 10,25 and $50 \%$ by volume, without any negative effects on barley germination and early growth found by biochar. In contrast to this, freshly produced, dried-rewetted HTC char often has quite negative effects (Busch et al. 2012; Bargmann et al. 2013; Jandl et al. 2013). It is now well known that fresh HTC char can contain components such as guaiacol, levulinic and glycolic acid (Bargmann et al. 2013; Jandl et al. 2013) that have germination- and growth-inhibiting properties. However, Busch et al. (2013) were able to show that these compounds can be easily degraded e.g. by co-composting. Afterwards, the positive properties of HTC char, such as the high cation exchange capacity came into play, and seedling growth was significantly improved. In this regard, HTC char is quite promising, but it likely needs a pre-treatment before using as soil additive, for removing the unstable, potentially phytotoxic, and $\mathrm{N}$-immobilising compounds. A potential pathway may be the inclusion of HTC char, produced from N-poor materials such as bark, Miscanthus straw or material from landscape conservation, in the production of composts intended for mixing with peat in growing media production. Composts are often produced at the facilities of peat-substrate producers, to ensure a constant and reproducible quality, and thus ensure the economic viability of the final end products, the peat-reduced or peat-free growing media. At the Austrian company Sonnenerde, Dunst (2015) successfully produces a wide range of biochar-containing compost-based and completely peat-free growing media that are sold to landscape architects, gardener markets and private gardeners.

In a Canadian study the effects of amendments of biochar for different organic soils and peat based substrate up to $50 \%$ had been evaluated in greenhouse experiments with tomato, sweet pepper, geranium and ornamental basil (Dorais et al. 2016). In accordance with other studies, a high percentage of biochar $(\geq 50 \mathrm{v} / \mathrm{v})$ decreased tomato plant height and total dry mass regardless of the types of soil. However, there was no interaction between biochar amendment and the plant pathogen Pythium ultimum. For any of the species studied no positive effect of biochar soil amendment on plant growth was observed. The authors concluded that a proportion of up to $30 \%$ of biochar can be used in replacement of peat for organic potted plants without any significant negative effect on plant growth and disease sensitivity. But this finding should be checked for other plant species and well characterised biochars in further studies. A more promising pathway to improve plant growth and health in plant nursery or horticulture seems to be the application of biochar in low doses of less than 1\% (Graber et al. 2014). Disease severity frequently exhibits a $U$-shaped response curve, with a minimum at some intermediate biochar dose. It is assumed that compounds found on chars such as n-alkanoic acids, hydroxyl and acetoxy acids, benzoic acids, diols, triols, and phenols, which are phytotoxic at high concentrations, may stimulate plant growth at low doses (hormesis, see Frenkel et al., this issue).

Although horticultural charcoal is on the market in Europe, USA, Japan and Brazil since a long time, there are still economic constraints, which did not enable the establishment of chars in growing media yet. Some commercial activities were reported during the EU COST meeting in Tartu. In Estonia, biochar is already used as absorbing agent in growing media as shown by Matogard company. Besides peat, compost, fertilisers, dolomite, perlite, wetting agent, humic materials, sand, clay, bark and ceramsite, charcoal is used as well to receive an output of about $300,000 \mathrm{~m}^{3}$ potting soils and compost per year (Matogard pers. comm.). A Finnish/Estonian example is the enterprise Biolan (pers. comm.), producing 8,000-10,000 tons of biochar annually since 2008. In 2013, Biolan was one of the first companies which introduced garden soil with addition of biochar to the market). In 2014, Biolan launched a new growing media containing wood-based biochar, chicken manure, peat and wood. 


\section{Conclusions}

Future horticulture will be increasingly demanding with respect to its requirements for the highest quality of growing media, and peat probably will remain the dominant growing media constituent in the EU for the next years. Constituents other than peat, coming mainly from local or regional sources, will increasingly be used in growing media as the demand and awareness by private customers is steadily rising. However, non-peat constituents will have to be (i) available reliably, (ii) of good quality, (iii) responsibly sourced and manufactured and (iv) they should be affordable.

Horticulturalists have already tested numerous materials, which had been considered as new constituents in growing media. But only few were successful. Wide practical experience as constituents of peat-based growing media already exists with compost, bark and fibre materials, although all of these residual materials are not sufficiently available. Therefore, the search for new alternatives is ongoing and char materials may become a new group with convincing properties in horticulture. In recent years, chars have been proved to enhance the biomass yield at biochar contents of up to $50 \%$ in growing media. This means that from a functional perspective, char materials must not necessarily remain on the level of a minor ingredient, but they may have the potential to become major constituents. Largest constraints are the limited amount of feedstocks available for carbonisation and the economic feasibility, even if waste material is being included as feedstock.

Biochar and HTC char may not only play a role as a substitute of peat, but also its synergy with peat and other constituents, which can lead to an added value of growing media. Biochar can be used in synergy with peat for example as a pH-controlling agent in acidic-peat based growing media, or as a disease suppressing component when used in low doses. Probably such combinations of peat with different alternative materials within growing media are the most promising ways forward. Particularly the combination of biochar and compost has shown favorable effects for water infiltration and retention as well as for nutrient cycling, simultaneously providing notable potential for long-term $\mathrm{C}$ sequestration.

Practical experience has already shown that chars can be applied as growing media constituents or additives at least in the sector of amateur gardeners. How far char materials can be established in the professional growing market will depend on the product performance that can be achieved with future research and development on the one hand, and on the other hand on the societal consensus to turn every-day $\mathrm{C}$ uses from being $C$ source processes to $C$ sinks, and to preserve the still existing peatlands.

\section{Acknowledgements}

This paper has been written within the framework of the EU COST Action TD1107 Biochar as option for sustainable resource management. The authors are grateful for funding the Meeting in Tartu. We like to thank Alar Astover and Henn Raave for their work as local organisers and for having the opportunity to get insight into both, in peat exploration and in undisturbed peatlands in Estonia.

\section{References}

Agegnehu, G.; Bass, A. M.; Nelson, P. N.; Bird, M. I. 2016. Benefits of biochar, compost and biochar-compost for soil quality, maize yield and greenhouse gas emissions in a tropical agricultural soil, Science of the Total Environment 543: 295-306. https://doi.org/10.1016/j.scitotenv.2015.11.054

Altland, J. E.; Locke, J. C. 2012. Biochar affects macronutrient leaching from a soilless substrate, HortScience 47: 1136-1140.

Bargmann, I.; Rillig, M.; Buss, W.; Kruse, A.; Kuecke, M. 2013. Hydrochar and biochar effects on germination of spring barley, Journal of Agronomy and Crop Science 199: 360-373. https://doi.org/10.1111/jac.12024

Baumgarten, A. 2013. European standardization of growing media analysis - a crtical review, Acta Horticulturae 1013: 59-64. https://doi.org/10.17660/ActaHortic.2013.1013.3

Bigelow, C. A.; Bowman, D. C.; Cassel, D. K. 2004. Physical properties of three sand size classes amended with inorganic materials or sphagnum peat moss for putting green rootzones, Crop Science 44: 900-907. https://doi.org/10.2135/cropsci2004.9000

Bonn, A.; Reed, M. S.; Evans, C. D.; Joosten, H.; Bain, C.; Farmer, J.; Emmer, I.; Couwenberg, J.; Moxey, A.; Artz, R.; Tanneberger, F.; Unger, von M.; Smyth, M.-A.; Birnie, D. 2014. Investing in nature: developing ecosystem service markets for peatland restoration, Ecosystem Services 9: 54-65. https://doi.org/10.1016/j.ecoser.2014.06.011

Brewer, J. S.; Baker, D. J.; Nero, A. S.; Patterson, A. L.; Roberts, R. S.; Turner, L. M. 2011. Carnivory in plants as a beneficial trait in wetlands, Aquatic Botany 94: 62-70. https://doi.org/10.1016/j.aquabot.2010.11.005

Bullock, A.; Acreman, M. 2003. The role of wetlands in the hydrological cycle, Hydrology and Earth System Sciences Discussions 7(3): 358-389. https://doi.org/10.5194/hess-7-358-2003

Busch, D.; Kammann, C.; Gruenhage, L.; Mueller, C. 2012. Simple biotoxicity tests for evaluation of carbonaceous soil additives: establishment and reproducibility of four test procedures, Journal of Environmental Quality 41: 1023-1032. https://doi.org/10.2134/jeq2011.0122

Busch, D.; Stark, A.; Kammann, C. I.; Glaser, B. 2013. Genotoxic and phytotoxic risk assessment of fresh and treated hydrochar from hydrothermal carbonization compared to biochar from pyrolysis, Ecotoxicology and Environmental Safety 97: 59-66. https://doi.org/10.1016/j.ecoenv.2013.07.003

Buss, W.; Graham, M. C.; Shepherd, J. G.; Masek, O. 2016. Risks and benefits of marginal biomass-derived biochars for plant growth, Science of the Total Environment 569: 496-506. https://doi.org/10.1016/j.scitotenv.2016.06.129

Butler, R. 2009. EU is 2nd largest source of peat emissions after Indonesia, finds global peat survey [online], [cited 12 May 
2016]. Available from Internet: https://news.mongabay. com/2009/11/eu-is-2nd-largest-source-of-peat-emissionsafter-indonesia-finds-global-peat-survey/

Casagrande, D.; Ferguson, A.; Boudreau, J.; Predny, R.; Folden, C. 1985. Organic geochemical investigations in the Okefenokee Swamp, Georgia: the fate of fatty acids, glucosamine, cellulose and lignin, in Compte Rendu, Neuvieme Congres International de Stratigraphie et de Geologie du Carbonifere, 17-26 May 1979, Washington and Champaign-Urbana, 4: 193-204.

CBD. 1992. Convention on Biological Diversity 1992. Rio de Janeiro, Brazil [online], [cited 5 June 1992]. Available from Interent: http://cil.nus.edu.sg/1992/1992-convention-onbiological-diversity/

CR 13456:1999. Soil Improvers and Growing Media - Labelling, Specifications and Product Schedules. CEN, European Committee for Standardisation, Brussels. $50 \mathrm{p}$.

Clarke, D.; Rieley, J. 2010. Strategy for responsible peatland management. International Peat Society.

Clymo, R. S.; Hayward, P. M. 1982. The ecology of Sphagnum, in Bryophyte ecology. Springer Netherlands, 229-289.

CoConcept. 2008. Socio-economic impact of the peat and growing media industry on horticulture in the EU. M. Altmann (Ed.). Report. i. 119 p.

De Tender, C. A.; Debode, J.; Vandecasteele, B.; D’Hose, T.; Cremelie, P.; Haegeman, A.; Ruttink, T.; Dawyndt, P.; Maes, M. 2016. Biological, physicochemical and plant health responses in lettuce and strawberry in soil or peat amended with biochar, Applied Soil Ecology 107: 1-12. https://doi.org/10.1016/j.apsoil.2016.05.001

Desbiens, M. C.; Bussieres, P.; Caron, J.; Beeson, R.; Haydu, J.; Boudreau, J.; Elrick, D. 2008. Improved water saving in nursery production using Sphagnum peat, Acta Horticulturae 779: 407-413. https://doi.org/10.17660/ActaHortic.2008.779.51

Directive 2000/76/EC of the European Parliament and of the Council of 4 December 2000 on the incineration of waste.

Dorais, M.; Martinez, C.; Diop, M.; Theriault, M.; Menard, C.; Pepin, S. 2016. Assessing the potential of biochar as a growing media component for potted plants, Acta Horticulturae 1137: 19-26. https://doi.org/10.17660/ActaHortic.2016.1137.3

Dudová, L.; Hájková, P.; Buchtová, H.; Opravilová, V. 2013. Formation, succession and landscape history of Central-European summit raised bogs: a multiproxy study from the Hrubý Jeseník Mountains, The Holocene 23: 230-242. https://doi.org/10.1177/0959683612455540

Dumroese, R. K.; Heiskanen, J.; Englund, K.; Tervahauta, A. 2011. Pelleted biochar: Chemical and physical properties show potential use as a substrate in container nurseries, Biomass \& Bioenergy 35(5): 2018-2027.

https://doi.org/10.1016/j.biombioe.2011.01.053

Dunn, C.; Freeman, C. 2011. Peatlands: our greatest source of carbon credits?, Carbon Management 2(3): 289-301. https://doi.org/10.4155/cmt.11.23

Dunst, G. 2015. Kompostierung und Erdenherstellung. Praxisbuch und Anleitung für Hausgarten, Landwirtschaft, Kommune und Profi. Riedlingsdorf: Verleger Sonnenerde - Gerald Dunst Kulturerden GmbH. 260 p.

European Biochar Foundation. 2012. European Biochar Certificate - Guidelines for a Sustainable Production of Biochar: Version 6.1 of 19th June 2015 [online]. Arbaz, Switzerland [cited 12 May 2016]. Available from: http://www.european-biochar. org/biochar/media/doc/ebc-guidelines.pdf.
Fornes, F.; Belda, R. M.; Lidon, A. 2015. Analysis of two biochars and one hydrochar from different feedstock: focus set on environmental, nutritional and horticultural considerations, Journal of Cleaner Production 86: 40-48. https://doi.org/10.1016/j.jclepro.2014.08.057

Foundation Responsibly Produced Peat [online]. 1.12.2014 [cited 12 May 2016]. Available from Internet: http://www.responsiblyproducedpeat.org/certification-system

Frenkel, O.; Jaiswal, A.; Elad, Y.; Lewi, B.; Kammann, C.; Graber, E. The effect of biochar on plant diseases: what should we learn while designing biochar substrates?, Journal of Environmental Engineering and Landscape Management (this issue).

Fuchsman, C. H. 1980. Peat, industrial chemistry and technology. London: Academic Press.

Gaskin, J. W.; Steiner, C.; Harris, K.; Das, K. C.; Bibens, B. 2008. Effect of low-temperature pyrolysis conditions on biochar for agricultural use, Transactions of the American Society of Agricultural and Biological Engineers 51: 2061-2069.

Glaser, B.; Wiedner, K.; Seelig, S.; Schmidt, H.-P.; Gerber, H. 2015. Biochar organic fertilizers from natural resources as substitute for mineral fertilizers, Agronomy for Sustainable Development 35: 667-678.

https://doi.org/10.1007/s13593-014-0251-4

Graber, E. R.; Frenkel, O.; Jaiswal, A. K.; Elad, Y. 2014. How may biochar influence severity of diseases caused by soilborne pathogens?, Carbon Management 5: 169-183. https://doi.org/10.1080/17583004.2014.913360

Hale, S. E.; Lehmann, J.; Rutherford, D.; Zimmerman, A. R.; Bachmann, R. T.; Shitumbanuma, V.; O’Toole, A.; Sundqvist, K. L.; Arp, H. P. H.; Cornelissen, G. 2012. Quantifying the total and bioavailable polycyclic aromatic hydrocarbons and dioxins in biochars, Environmental Science \& Technology 46: 2830-2838. https://doi.org/10.1021/es203984k

Hammer, E. C.; Forstreuter, M.; Rillig, M. C.; Kohler, J. 2015. Biochar increases arbuscular mycorrhizal plant growth enhancement and ameliorates salinity stress, Applied Soil Ecology 96: 114-121. https://doi.org/10.1016/j.apsoil.2015.07.014

Holden, J. 2005. Peatland hydrology and carbon release: why small-scale process matters, Philosophical Transactions of the Royal Society A: Mathematical, Physical and Engineering Sciences 363: 2891-2913. https://doi.org/10.1098/rsta.2005.1671

Immirzi, C. P.; Maltby, E.; Clymo, R. S. 1992. The global status of peatlands and their role in carbon cycling: a report for Friends of the Earth. London, UK: Friends of the Earth. 145 p.

IPCC. 2014. The 2013 supplement to the 2006 Guidelines for National Greenhouse Gas Inventories: Wetlands (Wetlands Supplement). Intergovernmental Panel on Climate Change.

IUSS Working Group WRB. 2007. World Reference Base for Soil Resources, first update 2007. World Soil Resources Reports 103. FAO, Rome.

Jandl, G.; Eckhardt, K. U.; Bargmann, I.; Kuecke, M.; Greef, J. M.; Knicker, H.; Leinweber, P. 2013. Hydrothermal carbonization of biomass residues: mass spectrometric characterization for ecological effects in the soil-plant system, Journal of Environmental Quality 42: 199-207.

https://doi.org/10.2134/jeq2012.0155

Janzen, H. H. 2004. Carbon cycling in earth systems-a soil science perspective, Agriculture, Ecosystems and Environment 104: 399-417. https://doi.org/10.1016/j.agee.2004.01.040

Joosten, H. 2009. The Global Peatland $\mathrm{CO}_{2}$ Picture: peatland status and drainage related emissions in all countries of the world. Wetlands International. Wageningen; Netherlands. 35 p. 
Joosten, H.; Clarke, D. 2002. Wise use of mires and peatlands. International Mire Conservation Group and International Peat Society. Saarijärvi, Finland. 304 p.

Kammann, C.; Borchard, N.; Cayuela, M.; Hagemann, N.; Ippolito, J.; Jeffery, S.; Kern, J.; Rasse, D.; Saarnio, S.; Schmidt, H.-P.; Spokas, K.; Wrage-Mönnig, N. Biochar as a novel tool to reduce the agricultural greenhouse-gas burden - knowns, unknowns and future perspectives, Journal of Environmental Engineering and Landscape Management (this issue).

Karhunen, A.; Laihanen, M.; Ranta, T. 2015. Supply security for domestic fuels at Finnish combined heat and power plants, Biomass and Bioenergy 77: 45-52.

https://doi.org/10.1016/j.biombioe.2015.03.019

Keddy, P. A. 2010. Wetland ecology. Cambridge University Press. https://doi.org/10.1017/CBO9780511778179

Khan, S.; Chao, C.; Waqas, M.; Arp, H. P. H.; Zhu, Y.-G. 2013. Sewage sludge biochar influence upon rice (Oryza sativa L.) yield, metal bioaccumulation and greenhouse gas emissions from acidic paddy soil, Environmental Science \& Technology 47: 8624-8632. https://doi.org/10.1021/es400554x

Kipp, J. A.; Wever, W.; de Kreij, C. 2000. International substrate manual. Doetinchem, The Netherlands: Elsevier International Business Information.

Koehler, A.-K.; Sottocornola, M.; Kiely, G. 2011. How strong is the current carbon sequestration of an Atlantic blanket bog?, Global Change Biology 17: 309-319.

https://doi.org/10.1111/j.1365-2486.2010.02180.x

Koster, E. A.; Favier, T. 2005. Peatlands, past and present, in E. A. Koster (Ed.). The physical geography of Western Europe. Oxford University Press, 161-182.

Kuzyakov, Y.; Bogomolova, I.; Glaser, B. 2014. Biochar stability in soil: decomposition during eight years and transformation as assessed by compound-specific ${ }^{14} \mathrm{C}$ analysis, Soil Biology and Biochemistry 70: 229-236.

https://doi.org/10.1016/j.soilbio.2013.12.021

Lanza, G.; Wirth, S.; Gessler, A.; Kern, J. 2015. Short-term response of soil $\mathrm{CO}_{2}$ respiration to addition of biochars: impact of fermentation post-processing and mineral nitrogen, Pedosphere 25(5): 761-769. https://doi.org/10.1016/S1002-0160(15)30057-6

Lawrence, W. J. C.; Newell, J. 1939. Seed and potting compost. London: Allen \& Unwin.

Lehmann, J.; Joseph, S. 2015. Biochar for environmental management: science, technology and implementation. Oxon, NewYork: Routledge.

Libra, J.; Ro, K.; Kammann, C.; Funke, A.; Berge, N.; Neubauer, Y.; Titirici, M.; Fühner, C.; Bens, O.; Kern, J.; Emmerich, K. 2011. Hydrothermal carbonization of biomass residuals: a comparative review of the chemistry, processes and applications of wet and dry pyrolysis, Biofuels 2(1): 71-106. https://doi.org/10.4155/bfs.10.81

Liu, J.; Schulz, H.; Brandl, S.; Miehtke, H.; Huwe, B.; Glaser, B. 2012. Short-term effect of biochar and compost on soil fertility and water status of a Dystric Cambisol in NE Germany under field conditions, Journal of Plant Nutrition and Soil Science 175: 698-707. https://doi.org/10.1002/jpln.201100172

Maher, M. J.; Prasad, M. 1993. Physical and chemical properties of fractioned peat, Acta Horticulturae 342: 257-264.

Maher, M. J.; Prasad, M.; Raviv, M. 2008. Organic soilless media components, in M. Raviv, J. H. Leith (Eds.). Soilless culture. Theory and practice. Amsterdam: Elsevier, 459-504. https://doi.org/10.1016/B978-044452975-6.50013-7
Marchán-Sanz, C.; Regueiro, M.; Barros, G. 2014. Panorama Minero [online]. Instituto Geológico y Minero de España (IGME). 366 p. [cited 12 May 2016]. Available from Internet: http://www.igme.es/PanoramaMinero/Panorama\%20 minero\%202014.pdf

Menberu, M. W.; Tahvanainen, T.; Marttila, H.; Irannezhad, M.; Ronkanen, A. K.; Penttinen, J.; Klove, B. 2016. Water-tabledependent hydrological changes following peatland forestry drainage and restoration: analysis of restoration success, $\mathrm{Wa}$ ter Resources Research 52: 3742-3760. https://doi.org/10.1002/2015WR018578

Méndez, A.; Paz-Ferreiro, J.; Gil, E.; Gascó, G. 2015. The effect of paper sludge and biochar addition on brown peat and coir based growing media properties, Scientia Horticulturae 193: 225-230. https://doi.org/10.1016/j.scienta.2015.07.032.

Michel, J.-C. 2010. The physical properties of peat: a key factor for modern growing media, Mires and Peat 6: 1-6.

Mitsch, W. J.; Gosselink, J. G. 2000. Wetlands. John Wiley \& Sons, Inc.

Montanarella, L.; Jones, R. J. A.; Hiederer, R. 2006. The distribution of peatland in Europe, Mires and Peat 1: Article 1. International Mire Conservation Group and International Peat Society.

Moore, P. D. 1989. The ecology of peat-forming processes: a review, International Journal of Coal Geology 12: 89-103. https://doi.org/10.1016/0166-5162(89)90048-7

Mukherjee, S.; Halder, G. 2016. Assessment of fluoride uptake performance of raw biomass and activated biochar of Colocasia esculenta stem: optimization through response surface methodology, Environmental Progress \& Sustainable Energy 35: 1305-1316. https://doi.org/10.1002/ep.12346

O’Toole, A.; Andersson, D.; Gerlach, A.; Glaser, B.; Kammann, C.; Kern, J.; Kuoppamäki, K.; Mumme, J.; Schmidt, H.-P.; Schulze, M.; Srocke, F.; Stenrod, M.; Stenström J. 2016. Current and future applications for biochar, in S. Shackley, G. Ruysschaert, K. Zwart, B. Glaser (Eds.). Biochar in European soils and agriculture. Science and Practice. Oxon: Routledge, 253-280.

Oleszczuk, R.; Szajdak, L.; Maryganova, V. 2008. Impacts of agricultural utilization of peat-soil on the greenhouse gas balance, Plant Soil 315: 3-17.

Parish, F.; Sirin, A.; Charman, D.; Joosten, H.; Minaeva, T.; Silvius, M. 2008. Assessment of peatlands, biodiversity and climate change. Global Environment Centre, Kuala Lumpur and Wetlands International. Wageningen. $179 \mathrm{p}$.

Prasad, M.; Carlile, W. R.; Maher, M. J. 2008. Research leads to building of 100,000 tonne compost facility for peat reduction, Paper 211, in $6^{\text {th }}$ International Conference Orbit 2008, 13-15 October 2008, Wageningen, The Netherlands.

Prasad, M.; Maher, M. J. 2013. Colour of peat as an indicator of chemical, biological and physical properties of peats, Acta Horticulturae 1013: 89-94. https://doi.org/10.17660/ActaHortic.2013.1013.8

Prasad, M. Unpublished data.

Prendergast-Miller, M.; Duvall, M.; Sohi, S. 2014. Biochar-root interactions are mediated by biochar nutrient content and impacts on soil nutrient availability, European Journal of Soil Science 65: 173-185. https://doi.org/10.1111/ejss.12079

Preston, M. D.; Basiliko, N. 2016. Carbon mineralization in peatlands: does the soil microbial community composition matter?, Geomicrobiology Journal 33: 151-162. https://doi.org/10.1080/01490451.2014.999293 
Ramchunder, S. J.; Brown, L. E.; Holden, J. 2012. Catchmentscale peatland restoration benefits stream ecosystem biodiversity, Journal of Applied Ecology 1: 182-191.

https://doi.org/10.1111/j.1365-2664.2011.02075.x

Reinikainen, O.; Korpi, J.; Tahvonen, R.; Näkkilä, J.; Silvan, N.; Silvan, K. 2012. Harvesting of Sphagnum biomass and its use as a growing medium constituent, in The $14^{\text {th }}$ International Peat Congress, Peatlands in Balance, 3-8 June 2012, Stockholm, Sweden.

Renou-Wilson, F.; Farrell, C. A. 2009. Peatland vulnerability to energy-related developments from climate change policy in Ireland: the case of wind farms, Mires and Peat 4: Article 08 [online]. International Mire Conservation Group and International Peat Society [cited 16 May 2009]. Available from Interent: http://www.mires-and-peat.net/

Rydin, H.; Jeglum, J. K. 2006. The biology of peatlands. Oxford: Oxford University Press.

https://doi.org/10.1093/acprof:oso/9780198528722.001.0001

Schimmelpfennig, S.; Glaser, B. 2012. One step forward toward characterization: some important material properties to distinguish biochars, Journal of Environmental Quality 41: 10011013. https://doi.org/10.2134/jeq2011.0146

Schmilewski, G. 2008. The role of peat in assuring the quality of growing media, Mires and Peat 3: Article 02. International Mire Conservation Group and International Peat Society.

Schulze, M.; Mumme, J.; Funke, A.; Kern, J. 2016. Effects of selected process conditions on the stability of hydrochar in low-carbon sandy soil, Geoderma 257: 137-145. https://doi. org/10.1016/j.geoderma.2015.12.018

Schumann, M.; Joosten, H. 2008. Global peatland restoration manual. Institute of Botany and Landscape Ecology, Greifswald University, Germany. 68 p.

Shackley, S.; Clare, A.; Joseph, S., McCarl, B. A.; Schmidt, H.-P. 2015. Economic evaluation of biochar systems: current evidence and challenges, in J. Lehmann, S. Joseph (Eds.). Biochar for Environmental management: science, technology and implementation. London, New York: Routledge, 813-852.

Shackley, S.; Ruysschaert, G.; Zwart, K.; Glaser, B. 2016. Biochar in European soils and agriculture. Science and practice. Oxon: Routledge.

Silvan, N.; Silvan, K.; Näkkilä, J.; Tahvonen, R.; Reinikainen, O. 2012. Renewability, use and properties of Sphagnum biomass for growing media purposes, in T. Magnusson (Ed.). Book of abstracts. The $14^{\text {th }}$ International Peat Congress, Peatlands in Balance, 3-8 June 2012, Stockholm, Sweden, 175-176.

Sohi, S.; Gaunt, J.; Atwood, J. 2013. Biochar in growing media: a sustainability and feasibility assessment. UK Biochar Research Centre. 84 p.

Steiner, C.; Harttung, T. 2014. Biochar as a growing media additive and peat substitute, Solid Earth 5: 995-999. https://doi.org/10.5194/se-5-995-2014

Steiner, C.; Sanchez-Monedero, M. A.; Kammann, C. 2015. Biochar as an additive to compost and growing media, in J. Lehmann, S. Joseph (Eds.). Biochar for environmental management: science, technology and implementation. London, New York: Routledge, 717-735.

Steiner, C.; Teixeira, W. G.; Woods, W. I.; Zech, W. 2009. Indigenous knowledge about Terra Preta Formation, in W. I. Woods, W. Teixeira, J. Lehmann, C. Steiner, A. M. G. A. WinklerPrins, L. Ribellato (Eds.). Amazonian dark earths: Wim Sombroek's vision. Springer.

Strack, M. 2008. Peatlands and climate change. International Peat Society A5, Jyväskylä, Finland. 223 p.

Tahvonen, R.; Näkkila, J.; Silvan, N.; Reinikainen, O. 2015. Production and use of sphagnum biomass as a plant substrate in greenhouse, in Book of abstracts. SusGro 2015, International Symposium on Growing Media, Composting and Substrate Analysis, 7-9 September 2015, Vienna, Austria, p. 45.

Tanneberger, F.; Wichtmann, W. 2011. Carbon credits from peatland rewetting Climate - biodiversity - land use: science, policy, implementation and recommendations of a pilot project in Belarus. Stuttgart, Germany: Schweizerbart Science Publishers. 223 p.

Tian, Y.; Sun, X.; Li, S.; Wang, H.; Wang, L.; Cao, J.; Zhang, L. 2012. Biochar made from green waste as peat substitute in growth media for Calathea rotundifola cv. Fasciata, Scientia Horticulturae 143: 15-18. https://doi.org/10.1016/j.scienta.2012.05.018

UBA. 2016. Chancen und Risiken des Einsatzes von Biokohle und anderer „veränderter" Biomasse als Bodenhilfsstoffe oder für die C-Sequestrierung in Böden. Umweltforschungsplan des Bundesministeriums für Umwelt, Naturschutz und Reaktorsicherheit. Texte 04/2016, Dessau-Roßlau. 254 p.

Van der Gaag, D. J.; van Noort, F. R.; Stapel-Cuijpers, L. H. M.; de Kreij, C; Termorshuizen, A. J.; van Rijn, E.; Zmora-Nahum, S.; Chen,Y. 2007. The use of green waste compost in peat-based potting mixtures: fertilization and suppressiveness against soilborne diseases, Scientia Horticulturae 114(4): 289-297. https://doi.org/10.1016/j.scienta.2007.06.018

Vaughn, S. F.; Kenar, J. A.; Thompson, A. R.; Peterson, S. C. 2013. Comparison of biochars derived from wood pellets and pelletized wheat straw as replacements for peat in potting substrates, Industrial crops and products 51: 437-443.

https://doi.org/10.1016/j.indcrop.2013.10.010

Veeken, A. H. M.; Blok, W. J.; Curci, F.; Coenen, G. C. M.; Termorshuizen, A. J.; Hamelers, H. V. M. 2005. Improving quality of composted biowaste to enhance disease suppressiveness of compost-amended, peat-based potting mixes, Soil Biology \& Biochemistry 37(11): 2131-2140. https://doi.org/10.1016/j.soilbio.2005.03.018

Verry, E. S.; Timmons, D. R. 1982. Nutrient flow through peatland, Ecology 63: 1456-1466. https://doi.org/10.2307/1938872

Wichtmann, W.; Schäfer, A. 2007. Alternative management options for degraded fens - Utilisation of biomass from rewetted peatlands, in T. Okruszko, E. Maltby, J. Szatylowicz, D. Swiatek, W. Kotowski. (Eds.). Wetlands: monitoring, modeling and management. London: Taylor \& Francis Group, 273-279.

World Energy Council. 2013. World Energy Resources. Chapter 6. 
Jürgen KERN. PhD, Senior Scientist of Biogeochemistry, Leibniz Institute for Agricultural Engineering and Bioeconomy, Germany, 1211 citations. H-index 16 (Google Scholar).

Priit TAMMEORG. DSc, Postdoctoral Researcher in Agroecology, Dept of Agricultural Sciences, University of Helsinki, 11 peer-reviewed articles in international scientific journals, H-index 6 (WoS).

Merrit SHANSKIY. PhD, Associated professor of Soil Science, Dept of Soil Science and Agrochemistry, Estonian University of Life Sciences. H-index 9 (Google Scholar).

Ruben SAKRABANI. PhD, Senior Lecturer in Soil Chemistry, Cranfield Soil and Agrifood Institute, Cranfield University, 30 peer-reviewed articles. H-index 10 (Google Scholar).

Heike KNICKER. PhD, Profesora de investigación, IRNAS-CSIC, 178 peer-reviewed articles in scientific journals, Hindex 48 (WoS).

Claudia KAMMANN. PhD, Professor for Climate Change Research for Special Crops, Institute for Soil Science and Plant Nutrition, Hochschule Geisenheim University, Geisenheim, Germany, 58 peer-reviewed articles in scientific journals, 7 book chapters, 2453 citations, h-index 27 (Google Scholar).

Eeva-Maria TUHKANEN. Former Luomala, PhD, Senior Research Scientist in Horticulture, Natural Resources Institute Finland. 10 peer-reviewed articles in international scientific journals, total number of publications 106.

Geerd SMIDT. PhD, Scientific director, European Competence Center for Peatland and Climate, Wagenfeld, Germany, 3 peer-reviewed articles in scientific journals, 3 book chapters.

Munoo PRASAD. PhD, Researcher/Owner, Compost/AD Research \& Advisory, Board Member, Irish Research Council of Science, Engineering \& Technology 2001-2006, Ireland, Special Scientist, Cyprus University of Technology Cyprus, 71 peer-reviewed articles in scientific journals, Editor, one book, author of 4 chapters of books and 2 two international patents.

Kari TIILIKKALA. DSc, Professor. Natural Resources Institute Finland (Luke), 41 peer-reviewed publications, total number of publications 350 .

Saran SOHI. PhD, Lecturer in Soil Science and Biochar, School of GeoSciences, University of Edinburgh, Scotland, 50 peer-reviewed publications, 4844 citations, H-index 32 (Google Scholar).

Gabriel GASCÓ. PhD, Associate Professor of Soil Science, School of Agricultural Engineering, Technical University of Madrid, Spain, 50 peer-reviewed articles in scientific journals. H-index 20 (Google Scholar).

Christoph STEINER. PhD, Research Associate and project coordination UrbanFood ${ }^{\text {Plus }}$, Organic Plant Production and Agroecosystems Research in the Tropics and Subtropics, University of Kassel, Germany, 16 peer-reviewed publications, 2 books, 1 edition, 19 book chapters, H-index 21 (Google Scholar).

Bruno GLASER. PhD, Professor of Soil Biogeochemistry, Institute of Agronomy and Nutritional Sciences, Martin Luther University Halle-Wittenberg, Germany, 137 peer-reviewed articles in scientific journals. H-index 37 (WoS). 